\title{
Changes in Body Composition, During the Season, in Highly Trained Soc- cer Players
}

\author{
Václav Bunc*, Pavel Hráský and Marie Skalská
}

Charles University Faculty of P.E. and Sports, Prague, Czech Republic

\begin{abstract}
Body composition (BC) and other functional parameters are the main predictors of fitness state in both trained and non-trained subjects. The selected parameters of the BC ( $\%$ of body fat $(\% \mathrm{BF})$, fat free mass (FFM), body cell mass $(\mathrm{BCM})$, extracellular mass (ECM), and $\mathrm{ECM} / \mathrm{BCM}$ relationship; all these parameters were determined by the whole body multi-frequency bioimpedance method) were determined four times per year in 45 top soccer players (January, March, July and December) (mean age $=21.9 \pm 3.1$ years, height $=179.5 \pm 4.0 \mathrm{~cm}$, mass $=75.3 \pm 6.0 \mathrm{~kg}, \% \mathrm{BF}=10.4 \pm 1.7 \%, \mathrm{FFM}=$ $67.6 \pm 4.1 \mathrm{~kg}, \mathrm{ECM} / \mathrm{BCM}=0.67 \pm 0.03, \mathrm{VO}_{2 \text { peak }} \cdot \mathrm{kg}^{-1}=62.7 \pm 3.8 \mathrm{ml} \cdot \mathrm{kg}^{-1} \cdot \mathrm{min}^{-1}, \mathrm{v}_{\text {peak }}=17.7 \pm 0.6 \mathrm{~km} \cdot \mathrm{h}^{-1}-1^{\text {st }}$ evaluation). The $\% \mathrm{BF}$ was altered during the training year by $9.9 \pm 1.8 \%$, FFM by $3.9 \pm 1.8 \%$, BCM by $8.0 \pm 1.4 \%$ and ECM/BCM by $13.8 \pm 2.1 \%$. The increase in body mass during a season is caused by increase in FFM and BCM and reflects qualitative alterations in training; mainly increase of training based on speed and strength. We may conclude that the parameters that characterize the BC may better reflect the changes in the quality and quantity of the imposed training load and/or training state than the maximal functional variables in highly trained soccer players and thus may be used like a supplementary criterion of imposed training effectivity.
\end{abstract}

Keywords: Body composition, bioimpedance, body cell mass, body mass, soccer players.

\section{INTRODUCTION}

Soccer is one of the most popular sports in the world, and its popularity is continuing to increase. There is still much uncertainty and debate surrounding its physiological requirement because emphasis is on skills to neglect of fitness, conservative training methods and the difficulty of studying the sport scientifically.

There is ample evidence to suggest that the position of the soccer players is related to both their energy demands and their physiological characteristics [1-5]. The frequently presented values for total distance covered in a game of above $10 \mathrm{~km}$ and maximal oxygen uptake over $60 \mathrm{ml} \cdot \mathrm{kg}^{-1} \cdot \mathrm{min}^{-1}$ suggest a moderate overall aerobic demand [4, 6-11].

The physical composition of the body is an important component of fitness. The excess adipose tissue is not active and encumbers athletes with useless weight [12]. This contributes to greater energy expenditure during a match and also decreases performance in terms of power and acceleration [4]. A professional player should keep his body composition close to an "ideal" value all season. For these reasons it is crucial for coaches to have knowledge and equipment to assess body composition. Anthropometric measurements have received widespread recognition in elite soccer player community. It is a fact that teams - players are characterized

*Address correspondence to this author at the Faculty of Physical Education and Sports Charles University, J. Martího 31, CZ 16252 Prague 6, Czech Republic; Tel: +420 220172338; E-mail: bunc@ftvs.cuni.cz by a relative large heterogeneity in body size. Several studies on anthropometric characteristics have been reported in the literature [13-15], but some of them only provided measurements at the beginning and at the end of the season.

Conditioning professionals should maintain optimum body composition throughout the season in all players, especially in a sport like soccer where excess fat mass and insufficient fat free mass could have a negative implication for performance. The reduction in the percentage of body fat and a simultaneous increase in the fat free body mass are significantly correlated with soccer players performance and, more specifically, with the repeated high intensity running ability and also with the amount of high intensity work performed during soccer games $[12,16]$.

Evaluation of changes in cardiorespiratory or metabolic variables during submaximal exercise may help to explain the adaptation (actual training state) of athletes to their training stimulus [4-17]. This is because maximal functional variables in homogeneous groups of trained subjects cannot adequately evaluate changes in the state of training. The changes observed in the maximal values of functional variables during the year are almost at the borderline of measurement error $[7,8]$.

The quality and/or an effect of imposed training process could be assessed by the changes of some functional variables that are influent by training. An assessment of body composition (BC) is necessary to properly identify a subject's predispositions for physical performance $[15,18,19]$. This assessment can then be used to estimate not only 
subject's ideal body mass but it is able to contribute to better formulate a training and diet regimen [20]. Periodic BC assessment can be used to assess the effectiveness of exercise and diet interventions or monitor changes in $\mathrm{BC}$ associated with growth and maturation and/or with highly intensive physical training.

Thus, there is a clinical need to measure not only percentage of body fat $(\% \mathrm{BF})$, but fat distribution, muscle mass, total body water (TBW), body-water compartments (extracellular - ECW, and intracellular water - ICW), bodywater volumes changes, extracellular mass - ECM, body cell mass - BCM, and bone mass as well [20-22].

In highly trained subjects the continuous monitoring of BC may contribute to regulation of training load in the training process and positively affect their form. The monitoring of $\mathrm{BC}$ may also be beneficial for the determination of an adequate volume of load in the design of exercise diagnostics [4].

Measuring BCM contents for the evaluation of muscle mass and protein tissue states in dependence of physical training and/or nutrition state is well accepted [22-25].

The importance of BC in soccer player performance remains unclear; however, it is a primary concern in conditioning programs throughout a season at all levels of competition. The inherent physical stress of practice sessions and competition during a season may modulate actual body composition [26].

Numerous tools and methodologies have been developed to measure various BC parameters. The bioelectrical impedance analysis seems to be one of the most commonly used methods in the field conditions. According to Ostojic [27] in athletes were found non-significant difference in body fat percentage determined by skinfold and whole body bioimpedance method.

Regardless of which instrument was used to assess the $\mathrm{BC}$, the method is only as good as the measurement technique and prediction or conversion formula applied. The conversion formulas and prediction equations selected use must be restricted to the populations from which they were derived to remain valid.

Data on variations in these parameters during the training year, no only at start and end training year, in soccer players are practically non-existent. The aim of this study was to assess the quantitative and qualitative changes in imposed training with help of selected BC and functional variables alterations in highly trained Czech adult soccer players during the training year.

\section{METHODS}

\section{Participants}

We tested 45 trained Czech soccer players (19 defenders, 15 midfielders, 11 forwards) underwent the $\mathrm{BC}$ and laboratory functional evaluation at pre-, mid-, end-, and pastseason in order to evaluate changes in $\mathrm{BC}$ and aerobic fitness on the treadmill during the training year. All subjects have been playing at least three years in the Czech $1^{\text {st }}$ league and more than $85 \%$ of these players were/are members of Czech national team.

We continuously monitor the training data, which were evaluated on the weekly cycles. We focused on fitness (endurance, speed and strength) and game training data.

\section{Procedures}

The selected parameters of the BC (\%BF, FFM, ECM, $\mathrm{BCM}$ and $\mathrm{ECM} / \mathrm{BCM}$, all were determined by the whole body multi-frequency bioimpedance measurement) four times per year (January, March, July and December).

Participants wore shorts and were asked to remove any metal and jewelry from their persons. Height determined by stadiometry and scale mass were recorded to the nearest 0.5 $\mathrm{cm}$ and $0.1 \mathrm{~kg}$, respectively (Seca 702, Seca $\mathrm{GmbH} \& \mathrm{Co}$. KG, Hamburg, Germany).

Body composition was measured using a bioelectrical impedance analyzer (B.I.A. 2000M, Data Input, Germany). The subjects refrained from physical activity, sauna, or alcohol consumption within 12 hours prior to the measurement of BC. During the measurement, the subjects lay supine on the examination table with arms away from the body with no shoes, socks, or any jewelry. Resistance and reactance were measured at four frequencies - 1, 5, 50 and $100 \mathrm{kHz}$ (B.I.A. 2000M, Data Input, Germany) on the right side of the body by tetrapolar electrode configuration (four electrodes, two on the hands and two on the feet in accordance with manufacturer's specification). The subjects remained lying until the completion of the measurement, and then resistance and reactance were recorded, which were later used to estimate muscle mass, ECM, BCM and ECM/BCM using body composition software (Nutri 4, Data Input, Germany). The calculation of $\% \mathrm{BF}$, FFM was realized by using prediction equations that were validated for athletes with help of DEXA according to Stewart and Hannan [28] and Wittich et al. [29].

Peak oxygen uptake was evaluated by means of an incremental exercise test to subjective exhaustion on a treadmill at 5\% inclination $[7,8]$. The respiratory variables and gas exchange were measured using an open system with the help of TEEM 100 diagnostic equipment.

\section{STATISTICAL ANALYSIS}

The means and standards deviations were used for presentation of assessed data. The Pearson correlation and Student t-test for paired values were used for statistical analyze of data. A p-value was set a priori of $<0.05$ to determine statistical significance. Institutional ethics approval was obtained from the Faculty of Physical Education and Sports Charles University Ethics Committee.

\section{RESULTS}

The seasonal variations of selected body composition variables are presented in Table 1. No significant differences were found in selected $\mathrm{BC}$ variables at the beginning and the season end. The statistical significance in followed variables in season is presented in Table 2 . 
Table 1. Seasonal variations of selected body composition and functional variables that were determined in 45 highly trained Czech soccer players.

\begin{tabular}{|c|c|c|c|c|c|}
\hline & January & March & July & December & $\Delta \max (\%)$ \\
\hline Body mass (kg) & $75.3 \pm 6.0$ & $75.6 \pm 5.9$ & $77.4 \pm 5.8$ & $75.0 \pm 6.0$ & $3.1 \pm 0.5$ \\
\hline Height (cm) & $179.5 \pm 4.0$ & $179.4 \pm 4.1$ & $179.5 \pm 4.0$ & $179.5 \pm 4.0$ & --- \\
\hline Body fat (kg) & $7.9 \pm 2.4$ & $7.3 \pm 2.1$ & $7.3 \pm 2.2$ & $7.6 \pm 2.5$ & $7.6 \pm 1.9$ \\
\hline$\%$ Body fat $(\%)$ & $10.5 \pm 1.9$ & $9.7 \pm 2.0$ & $9.5 \pm 1,8$ & $10.2 \pm 1.7$ & $9.9 \pm 1.8$ \\
\hline FFM (kg) & $67.4 \pm 4.1$ & $68.3 \pm 3.8$ & $70.1 \pm 3.9$ & $67.4 \pm 4.0$ & $3.9 \pm 1.8$ \\
\hline $\mathrm{ECM}(\mathrm{kg})$ & $26.9 \pm 1.1$ & $26.5 \pm 1.0$ & $26.3 \pm 0.9$ & $26.8 \pm 1.2$ & $1.9 \pm 0.7$ \\
\hline $\mathrm{BCM}(\mathrm{kg})$ & $40.6 \pm 1.7$ & $41.9 \pm 2.5$ & $44.4 \pm 2.5$ & $41.2 \pm 2.8$ & $8.0 \pm 1.4$ \\
\hline $\mathrm{BCM}$ in $\% \mathrm{BM}(\%)$ & $66.3 \pm 1.8$ & $63.3 \pm 2.0$ & $59.2 \pm 1.8$ & $65.1 \pm 1.7$ & $10.7 \pm 0.8$ \\
\hline $\mathrm{ECM} / \mathrm{BCM}$ & $0.66 \pm 0.03$ & $0.63 \pm 0.02$ & $0.58 \pm 0.04$ & $0.65 \pm 0.04$ & $13.8 \pm 2.1$ \\
\hline $\mathrm{VO}_{2 \text { peak }} \cdot \mathrm{kg}^{-1}(\mathrm{ml})$ & $62.7 \pm 3.8$ & $64.9 \pm 4.0$ & $63.7 \pm 4.1$ & $62.3 \pm 3.7$ & $4.0 \pm 0.8$ \\
\hline $\mathrm{v}_{\text {peak }}\left(\mathrm{km} \cdot \mathrm{h}^{-1}\right)$ & $17.5 \pm 0.6$ & $18.1 \pm 0.7$ & $18.4 \pm 0.6$ & $17.7 \pm 0.7$ & $5.1 \pm 1.2$ \\
\hline
\end{tabular}

1 - January, 2 - March, 3 - July, 4 - December

Table 2. Statistical significance of selected BC and functional variables assessed with help of paired t-test in highly trained soccer players during the season.

\begin{tabular}{|c|c|c|c|c|c|c|}
\hline & $1-2$ & $1-3$ & $1-4$ & $2-3$ & $2-4$ & $3-4$ \\
\hline Body mass (kg) & NS & 0.005 & NS & 0.005 & NS & NS \\
\hline Height (cm) & NS & NS & NS & NS & NS & NS \\
\hline Body fat (kg) & NS & 0.005 & NS & NS & NS & 0.005 \\
\hline$\%$ Body fat (\%) & NS & 0.005 & NS & NS & NS & 0.005 \\
\hline FFM (kg) & NS & 0.005 & NS & 0.005 & NS & 0.005 \\
\hline ECM (kg) & NS & NS & NS & NS & NS & NS \\
\hline BCM (kg) & NS & 0.005 & NS & 0.005 & NS & 0.005 \\
\hline $\mathrm{BCM}$ in $\% \mathrm{BM}(\%)$ & 0.05 & 0.001 & NS & 0.005 & NS & 0.001 \\
\hline $\mathrm{ECM} / \mathrm{BCM}$ & NS & 0.005 & NS & NS & NS & 0.005 \\
\hline $\mathrm{VO}_{2 \text { peak }} \cdot \mathrm{kg}^{-1}(\mathrm{ml})$ & NS & NS & NS & NS & NS & NS \\
\hline$v_{\text {peak }}\left(\mathrm{km} \cdot \mathrm{h}^{-1}\right)$ & NS & 0.005 & NS & NS & NS & NS \\
\hline
\end{tabular}

$0.05-\mathrm{p}<0.05, \mathrm{NS}-$ non significant

The highest body mass, fat free mass and BCM and lowest values of $\% \mathrm{BF}$ and $\mathrm{ECM} / \mathrm{BCM}$ relationship were detected in July. This increase was affected by a significant increase of speed and strength training load - the increase began at $5.3 \%$ during the $1^{\text {st }}$ evaluation and ended at $12.5 \%$ of total volume of training loads at the $3^{\text {rd }}$ evaluation. These alterations could be explained as the "improvement of muscle mass quality", and may be use in practice for evaluation of intensive training effect; loads with higher content of movement intensities.
Maximal seasonal variations in $\mathrm{BC}$ variables $(\% \mathrm{BF}$ was altered by $9.9 \pm 1.8 \%$, FFM by $3.9 \pm 1.8 \%$, BCM by $8.0 \pm 1.4 \%$, $\mathrm{ECM} / \mathrm{BCM}$ by $13.8 \pm 1.9 \%$ ) were significantly higher than alterations in other functional variables $\left(\mathrm{VO}_{2 \text { peak }} \cdot \mathrm{kg}^{-1} \mathrm{o}\right.$ $4.0 \pm 0.9 \%$ and $\mathrm{v}_{\text {peak }}$ about of $5.1 \pm 1.4 \%$ ).

We did not found any significant differences in BC variables between defenders, midfielders, and forwards. These data were significantly better than the data in goalkeepers. 
In functional variables the data in midfielders were significantly higher $(\mathrm{p}<0.05$ in all cases $)$ than data in defenders and forwards. Data in all players from filed were better than data in goalkeepers.

The mean values of ECM/BCM relationship that were determined in other groups of athletes by the same way like data in soccer players are presented in Table 3.

Table 3. Mean $\pm \mathbf{s}_{\text {D }}$ values of $\mathbf{E C M} / \mathbf{B C M}$ relationship determined by whole body multi-frequency bioimpedance method in trained Czech athletes of different sport events.

\begin{tabular}{|c|c|c|}
\hline & Men/N & Women/N \\
\hline \hline Ice hockey & $0.58 \pm 0.03 / 386$ & $0.69 \pm 0.03 / 42$ \\
\hline Soccer players & $0.64 \pm 0.04 / 493$ & $0.70 \pm 0.02 / 51$ \\
\hline Cross country skiers & $0.67 \pm 0.02 / 201$ & $0.70 \pm 0.03 / 101$ \\
\hline Biathlon & $0.68 \pm 0.03 / 156$ & $0.71 \pm 0.04 / 85$ \\
\hline Tennis & $0.70 \pm 0.04 / 62$ & $0.74 \pm 0.04 / 34$ \\
\hline Endurance runners & $0.71 \pm 0.03 / 126$ & $0.75 \pm 0.03 / 74$ \\
\hline Swimmers & $0.72 \pm 0.05 / 34$ & $0.76 \pm 0.04 / 31$ \\
\hline Non-trained & $0.78 \pm 0.05 / 563$ & $0.82 \pm 0.03 / 345$ \\
\hline
\end{tabular}

The dependence of peak oxygen uptake on relationship $\mathrm{ECM} / \mathrm{BCM}$ by the $1^{\text {st }}$ evaluation has a form:

$\mathrm{VO}_{2 \text { peak }} \cdot \mathrm{kg}^{-1}(\mathrm{ml})=-55.584 * \mathrm{ECM} / \mathrm{BCM}+99,590, \mathrm{r}^{2}=$ $0.701, \mathrm{~S}_{\mathrm{EE}}=2.24 \mathrm{ml}, \mathrm{p}<0.005$

The coefficient determination in these relationships altered in dependence on season - according to alterations in quantity and quality of imposed training load. In January $r^{2}=$ 0.705 , March $r^{2}=0.712$, July $r^{2}=0.721$, and December $r^{2}=$ 0.708 .

The values of $\mathrm{BCM}$ in relative description like a percentage of BM are lying practically in the range from 60 to $65 \%$ of BM that was presented by Andreoli et al. [2003].

In 1st evaluation we found the significant dependence of peak oxygen uptake on BCM in the form:

$\mathrm{VO}_{2 \text { peak }} \cdot \mathrm{kg}^{-1}(\mathrm{ml})=1.002 * \mathrm{BCM}(\mathrm{kg})+21,235, \mathrm{r}^{2}=$ $0.581, \mathrm{~S}_{\mathrm{EE}}=2.91 \mathrm{ml}, \mathrm{p}<0.01$

The coefficient determination in these relationships altered in dependence on season similarly like in above presented dependence of peak oxygen uptake on ECM/BCM. In January $\mathrm{r}^{2}=0.581$, March $\mathrm{r}^{2}=0.611$, July $\mathrm{r}^{2}=0.631$, and December $\mathrm{r}^{2}=0.590$, and thus probably reflects the seasonal alteration in quantity and quality of imposed training load.

\section{DISCUSSION}

Body composition is a key consideration in the physical make-up of professional soccer players [5], and significantly reflects the quantitative and qualitative changes in imposed training. From this point of view we found the highest changes in these variable in pre- a past-season evaluation.

Body mass measures in this study were similar to those previously reported for older soccer players $[1,5,13-16,19$, $30-34]$. In addition, the $\% \mathrm{BF}$ was similar to that reported in other studies $[8,20,22,26,35]$. These results confirm that high-level soccer players are, according to $\mathrm{BC}$ variables, relatively homogeneous [4]. The significant increase in BM from PRE to POST might be reasoned as being detrimental to competitive performance; however, $60 \%$ of the increase in body mass was explained by a gain in lean tissue [5-12].

Unfortunately, we did not find, in published literature available to us, information about changes in ECM and BCM in trained soccer players during a training year, so our data cannot be compared. If comparing the soccer players' data with sports that are energetically and characteristically similar, as in ice hockey, see Table $\mathbf{3}$, we can find similar parameters. These parameters are clearly the result of the nature and character of training used in games - mainly intermittent loads with high intensity of exercise $[6,8]$.

The main finding of the present study was that body fat content of elite professional soccer players significantly dropped during the conditioning and competitive period and increased during the off-season, furthermore that the functional variables (i.e. peak oxygen uptake) are strongly dependent on "quality" of muscle mass, mainly on the BCM and/or ECM/BCM relationship.

Players with the lowest percentage of body fat often have a better performance. Because body fat is a direct reflection of the intensity of training [21,32], the BC of soccer players is likely to change during the course of the competitive season as a result of training, competition, and diet [21]. In general, the results showed that the size and body composition in the soccer elite players of Czech Republic are similar in relation to international studies. As to the playing positions, there were no significant differences, except that the soccer players who serve as midfielders are those who have only low values of $\mathrm{BF}$ with relation to the other playing positions and they are lower and lighter with regard to the goalkeepers [1].

Sutton et al. [5] found differences in BC that were evident between goalkeepers and outfield players, but not between outfield playing positions. No differences were found on the basis of international status. The non-Caucasian players demonstrated significantly lower percent body fat $(9.2$ $+/-2.0 \%)$ than the Caucasian players $(10.7+/-1.8 \%)$.

Similar changes in $\mathrm{BF}$ and $\% \mathrm{BF}$ and FFM was found by Milanese et al. [33]. Their results in Italy professional soccer players showed that whole-body FM and \%FM significantly $(\mathrm{p}<0.001)$ decrease at mid-season $(-11.9 \% ;-1.3 \%$, respectively) and end-season $(-8.3 \% ;-0.8 \%$, respectively) whereas fat-free soft tissue mass (FFSTM) significantly $(\mathrm{p}<0.001)$ increase at mid-season $(+1.3 \%)$ and end-season $(+1.5 \%)$. It was concluded that professional soccer players undergo changes in their FM, FFSTM, and mineral mass across the season with some regional variations, irrespective of the playing position. Changes are mostly positive at midseason, possibly due to difference in training between the first and second phase of the season. 
The BF contents in this study were similar to those previously reported in data of similarly aged soccer players [26]. Sutton et al. [5] presented in non-Caucasian players significantly lower \%BF $(9.2+/-2.0 \%)$ than in the Caucasian players $(10.7+/-1.8 \%)$. The percent of $\mathrm{BF}$ values that were presented by Silvestre et al. [26] (defenders 10.6+2.1\%, midfielders $10.2+1.8 \%$, forwards $9.9+2.0 \%$ ) were broadly similar to the values reported by Davis et al. [9] (defenders $10.7+2.0 \%$, midfielders $10.6+2.1 \%$, forwards $10.0+1.8 \%$ ) and Arnason et al. [37] (defenders 10.6+3.6\%, midfielders $10.7+4.2 \%$, forwards $9.6+5.1 \%$ ); all of these results conform to the $10 \%$ average body fat for competitive male soccer players reported by Rico-Sanz [34]. The similarities in findings, in spite of different methods of assessment, testify to the homogeneity of elite outfield soccer players [17].

The significant seasonal increase in body mass might be reasoned as being detrimental to competitive performance; however, $60 \%$ of the increase in body mass may be explained by a gain in lean tissue [12]. Presumably, increases in lean tissue primarily resulted from gains in muscle tissue, suggesting that an athlete's strength also would improve [26]. Lean tissue significantly increased in the trunk and the legs. This may have happened due to a conditioning program that can be characterized as total conditioning, with the continuous development of aerobic capacity, power, speed, and speed endurance designed to maintain and improve physical performance with associated benefits in body composition $[4,6,8,11]$.

Body composition is a key consideration in the physical make-up of professional soccer players. The aims of the present study were to determine whether the $\mathrm{BC}$ of professional soccer players varied during the training year. One aim of $\mathrm{BC}$ assessment is to differentiate and quantify different body compartments. In professional soccer players, assessments are used alongside fitness measurements to determine physical preparedness for competition and to monitor the effects of training and dietary interventions on body composition status. Excess fat mass acts as a dead weight in activities in which the body is lifted repeatedly against gravity [4]. This excess weight has a deleterious effect upon general locomotion and soccer-specific actions such as jumping to contest aerial possession of the ball. The fat-free compartment, which includes lean muscle mass and bone mineral mass, is important for the production of speed, strength and power, and for injury prevention $[13,17,32]$.

Differences in BCM exist among athletes of different sports, and among athletes within the same sport who compete at different performance levels [38].

The physical performance is caused by actual state of functional variables and muscle state. Both these groups of predispositions are strongly depending on a quality of imposed training load, mainly on the level of exercise intensity. The decisive is in majority of movement and/or sports activities the volume of strength and speed training $[17,23,35$, $36,38]$. This could be confirmed by data from different sport events that are presented in Table 2 .

The lowest values of relationship ECM/BCM were found in athletes with higher part of speed and/or strength activities ice hockey players. Oppositely the highest values and the lowest actual predisposition for physical exercise were found in non-trained subjects of the same age [21].

The data in female athletes of similar training state are slightly lower than in male. This could be explained by a higher muscle mass in males than in females and a better predisposition for highly intensive exercise in males what is following from higher percentage of FT fibers in their muscles $[8,18]$.

The cause of significantly higher changes in $\mathrm{BC}$ than in functional variables connected with peak oxygen uptake could be found in the structure and orientation of imposed training and in the selectivity of followed variables on the used training stimulus [8]. We may conclude that the parameters that may characterize the $\mathrm{BC}$ better reflect the changes in the quality and quantity of the imposed training load and/or training state than the maximal functional variables in highly trained subjects. Thus the $\mathrm{BC}$ is an important determinant of functional and training state in highly trained subjects that cannot be overlooked. Variations in the $\mathrm{ECM} / \mathrm{BCM}$ index were due to accretion of BCM, which was associated with quality of imposed training load and with an increase of ICW $[22,23]$.

A maximal oxygen uptake of $60 \mathrm{ml} \cdot \mathrm{kg}^{-1} \cdot \mathrm{min}^{-1}$ seems to be adequate even at high levels of the game in adults, though there are commentators on the game who believe that a figure of $65 \mathrm{ml} \cdot \mathrm{kg}^{-1} \cdot \mathrm{min}^{-1}$ in adult soccer players is necessary $[4,6,11]$. Soccer player's values $60 \mathrm{ml} \cdot \mathrm{kg}^{-1} \cdot \mathrm{min}^{-1}$ are about $10 \mathrm{ml} \cdot \mathrm{kg}^{-1} \cdot \mathrm{min}^{-1}$ above the mean values that were collected in the general population of the same age, but are in turn at least $15 \mathrm{ml} \cdot \mathrm{kg}^{-1} \cdot \mathrm{min}^{-1}$ below those obtained in true endurance athletes, for example, long-distance runners and crosscountry skiers $[8,18]$. Soccer players, therefore, seem to have good but not outstanding aerobic capacity.

The dilemma for the coach and player is to determine how to accomplish improvements in fitness through an organized fitness program without sacrificing the ability to perform well in game after game or neglecting the skills which gave soccer play its unique character [4]. This is very important especially in very young soccer players which must firstly improve the basic motor abilities. It is likely that an increase in fitness will be able to be capitalized on only if there is an increase in the player's skill and game sense, and the reverse may apply also $[6,16]$.

Any change in these variables can only result from basic alterations in the quality and, in particular, the quantity of training of top soccer players. These changes are most unlikely to occur during a single year. This means that the maximal oxygen uptake can be changed during training in trained athletes only with great difficulty and it has little practical use for evaluating influence of the training stimulus on the course of adaptation to this level of exercise $[4,7,9$, 39]. Attention should be directed to how the necessary properties and prerequisites of running performance can best be developed during the whole training year.

It may be concluded that $\mathrm{BC}$ is important for elite soccer players, but that homogeneity between players at top professional level results in little variation between individuals. The variation during the season could significantly be higher than in inter-individual differences. 


\section{CONCLUSION}

We can conclude that in trained soccer players the $\mathrm{BC}$ evaluation could be used for evaluation of qualitative and quantitative alterations in the imposed training load. Body cell mass, measured using the whole body multi-frequency bioimpedance method, represents an innovative, simple approach to assess $\mathrm{BC}$.

The present study demonstrates that it is very important to analyze $\mathrm{BC}$ in soccer players, not only with the aim to evaluate the variation of weight in a quantitative and qualitative way, but also with the purpose of imposed training assessment. Although these results must be considered not yet conclusive, they could be the important information for coaches, especially during the selection of young soccer players.

Changes in $\mathrm{BC}$ were similar for all playing positions. It may be concluded that professional soccer players undergo changes in their FM, FFM, BCM, ECM and ECM/BCM across the season with some regional variations, irrespective of the playing position. Changes are mostly positive at midseason, possibly due to difference in training between the first and second phase of the season.

\section{CONFLICT OF INTEREST}

The authors confirm that this article content has no conflict of interest.

\section{ACKNOWLEDGEMENTS}

The study was supported by a grant from the Czech Ministry of Education MSM 0021620864 and a grant from Charles University P38

\section{REFERENCES}

[1] Cossio-Bolanos M, Portella D, Hespanhol JE, Fraser N, De Arruda M. Body size and composition of the elite peruvian soccer player. $\mathrm{J}$ Exerc Physiol 2012; 15(3): 30-9.

[2] Di SV, Pigozzi F. Physical training of football players based on their positional rules in the team. J Sports Med Phys Fitness 1998; 38(4): 294-7.

[3] Kalapotharakos VI, Strimpakos N, Vithoulka I, Karvounidis C, Diamantopoulos K, Kapreli E. Physiological characteristics of elite professional soccer teams of different ranking. J Sports Med Phys Fitness 2006; 46: 515-9.

[4] Reilly T. Fitness assessment. In: Reilly T, Ed. Science and Soccer. London: E \& FN Spon 1996; pp. 25-47.

[5] Sutton L, Scott M, Wallace J, Reilly T. Body composition of English premier league soccer players: influence of playing position, international status, and ethnicity. J Sports Sci 2009; 27(10): 101926.

[6] Bangsbo J. Physiology of soccer. Copenhagen: Storm 1993.

[7] Bunc V, Heller J, Leso J, Šprynarová Š, Zdanowicz R. Ventilatory threshold in various groups of highly trained athletes. Int J Sports Med 1987; 8(4): 275-80.

[8] Bunc V. Biocybernetic approach to evaluation of organism response to physical load. Prague: Charles University 1989.

[9] Davis JA, Brewer J, Atkin D. Pre-season physiological characteristics of english first and second division soccer players. J Sports Sci 1992; 10: 541-7.

[10] Ekblom B. Applied physiology of soccer. Sports Med 1986; 3: 5060.

[11] Tumilty D. Physiological characteristics of elite soccer players. Sports Med 1993; 16(2): 80-96.
Kraemer WJ, French DN, Paxton NJ, et al. Changes in exercise performance and hormonal concentrations over a big ten soccer season in starters and nonstarters. J Strength Cond Res 2004; 18: 121-8.

[13] Aziz AR, Tan YH. Variation in selected fitness attributes of professional soccer players during a league season. In: Reilly T, Cabri J, Araujo D, Eds. Science and Football V, London: Routlege 2005; pp. 134-8.

[14] Carling C, Orhant E. Variation in body composition in professional soccer players: interseasonal and intraseasonal changes and the effects of exposure time and player position. J Strength Cond Res 2010; 24(5): 1332-9.

[15] Kutlu M, Sofi N, Bozkus T. Changes in body compositions of elite level amateur and professional soccer players during the competitive season. J Sports Sci Med 2007; 7: 53-9.

[16] Reilly T, Bangsbo J, Franks A. Anthropometric and physiological predispositions for elite soccer. J Sports Sci 2000; 18: 669-83.

[17] Astrand PO, Rodahl K. Textbook of work physiology. New York: McGaw Hill 1986.

[18] Casajus JA. Seasonal variation in fitness variables in professional soccer players. J Sports Med Phys Fitness 2001; 41: 463-9.

[19] Michailidis Y, Michailidis C, Primpa E, et al. Changes of body composition in professional soccer players during the season. Serb J Sports Sci 7(1): 39-44.

[20] Heyward VH, Wagner DR. Applied body composition assessment. Champaign: Human Kinetics 2004.

[21] Bunc V, Skalská M. Are the children's predispositions for physical exercise influenced by their body mass? Am J Sports Sci Med 2014; 2(5): 177-80.

[22] Roche AF, Heymsfield SB, Lohman TG. Human body composition. Champaign: Human Kinetics 1996.

[23] Bunc V, Štilec M. Tělesné složení jako indikátor aktivního životního stylu seniorek. (Body composition like an indicator of active life style in senior women). Czech Kinatropol 2007; 11(3): 1723.

[24] Oliveira CMC, Kubrusly M, Mota RS, Silva CAB, Choukroun G, Oliveira VN. The phase angle and mass body cell as markers of nutritional status in hemodialysis patients. J Renal Nutr 2010; 20(5): 314-20.

[25] Talluri A, Liedtke R, Mohamed EI, Maiolo C, Martinoli R, De Lorenzo A. The application of body cell mass index for studying muscle mass changes in health and disease conditions. Acta Diabet 2003; 40: S286-9.

[26] Silvestre R, Kraemer WJ, West C, et al. Body composition and physical performance during a national collegiate athletic association division i men's soccer season. J Strength Cond Res 2006; 20(4): 962-70.

[27] Ostojic SM. Estimation of body fat in athletes: skinfolds $v s$ bioelectrical impedance. J Sports Med Phys Fitness 2006; 46(3): 442-6.

[28] Stewart AD, Hannan WJ. Prediction of fat and fat-free mass in male athletes using dual X-ray absorptiometry as the reference method. J Sports Sci 2000; 18: 263-74.

[29] Wittich A, Olivery MB, Rotemberg E, Mautalen DC. Body composition of professional football (soccer) players determined by dual x-ray absorptiometry. J Clin Densitom 2001; 4: 51-5.

[30] De Araujo SS, Mesquita RR, Dos Santos RM, Oliveira EL, Alves RA. Anthropometric, functional, and metabolic profiles of soccer players. J Exerc Physiol 2012; 15(6): 37-47.

[31] Hazir T. Physical characteristics and somatotype of soccer players according to playing level and position. J Human Kinetics 2010; 26: 83-95.

[32] Iga J, Scott M, George K, Drust B. Seasonal changes in multiple indices of body composition in professional football players. Int J Sports Med 2014; 35(12): 994-8.

[33] Milanese C, Cavedon V, Corradini G, De Vita F, Zancanaro C. Seasonal DXA-measured body composition changes in professional male soccer players. J Sports Sci 2015, 33(12): 121928.

[34] Rico-Sanz J. Body composition and nutritional assessments in soccer. Int J Sport Nutr 1998; 8: 113-23

[35] Westerterp KR, Meijer AL, Janssen ME, Saris HM, Hoor FT. Long-term effect of physical activity on energy balance and body composition. Br J Nutr 1992; 68: 21-30.

[36] Arnason A, Sigurdsson A, Gudmundsson I, Holme L, Engebretsen L, Bahr R. Physical fitness, injuries and team performance in soccer. Med Sci Sports Exerc 2004; 36: 278-85. 
[37] Melchiorri G, Monteleone G, Andreoli A, Calla C, Sgroi M, De Lorenzo A. Body cell mass measured by bioelectrical spectroscopy in professional football (soccer) players. J Sport Med Phys Fitness 2007; 47(4): 408-12.
[38] Andreoli A, Melchiorri G, Brozzi M, et al. Effect of different sports on body cell mass in highly trained athletes. Acta Diabetologica 2003; 40: S122-5.

[39] Rhodes EC, Mosher RE, Mckenzie DC, Franks IM, Potts JE. Physiological profile of the Canadian olympic soccer team. Can J Appl Sport Sci 1986; 11(1): 31-6.

Received: January 15, 2015

Revised: September 17,2015

Accepted: September 18, 2015

(C) Bunc et al.; Licensee Bentham Open.

This is an open access article licensed under the terms of the Creative Commons Attribution-Non-Commercial 4.0 International Public License (CC BY-NC 4.0) (https://creativecommons.org/licenses/by-nc/4.0/legalcode), which permits unrestricted, non-commercial use, distribution and reproduction in any medium, provided the work is properly cited. 